\title{
REP0RT OF THE COUNCIL
}

\section{$\mathrm{OF}$ \\ THE CAMDEN SOCIETY,}

ELECTED 2nd MAY 1866.

The Council of the Camden Society, elected on the 2nd May 1866, have to express their regret that the Obituary of the Society for the present year contains the names of several Members whose loss is extremely to be lamented. Foremost in the melancholy register stands the late President of the Socrety, the Most Honourable The MarQuess Camden, K.G., and his name is followed by those of,

Thomas Batcheldor, Esq. F.S.A.

Robert Bell, Esq.

John Jackson Blandy, Esq. Local Secretary for Reading.

Right Hon. Sir James Lewis Knight Bruce, F.R.S., F.S.A.

Henry Jackson, Esq.

Sir Thomas Rokewode Gage, Bart.

John Gideey, EsQ.

The LORD IVoRY.

Henry Eyres Landor, Esq.

James Lucas, Esq.

Maurice Peter Moore, Esq.

Kenyon S. Parker, Esa.

Henry Crabb Robinson, Esq. F.S.A.

Right Hon. Sir James Wigram, M.A., F.R.S., F.S.A.

Newman Smith, Esq.

Mrs. Thornhill.

Charles M. Willich, Esq.

Francis John Wright, Esq.

On the occurrence of the death of the late President, the Council immediately held a Special Meeting, and passed the following Resolution of sympathy and condolence :- 
"That this Council has received the startling tidings of the death of its President with the most sincere regret. His Lordship's constant presence at the Meetings of the Council, the patient and considerate kindness with which he presided over its consultations, and the readiness with which he gave his name and influence to any measure deemed likely to benefit the Society, have justly attached every Member of the Council to his person and presidency. His loss is deeply lamented; and the Council directs that this expression of its feeling be not only entered on its proceedings, but be communicated to the family of the late Marquess, with a strong assurance of the sympathy and condolence of the Council, on their great bereavement."

A special General Meeting of the Society subsequently expressed its full concurrence in the resolution of the Council; and the resolutions, both of the Council and the Society, were duly transmitted to the present Marquess, and by him most kindly acknowledged. The Council recalls attention to the subject on the present occasion, in order to put on permanent record the evidence that this Society was not wanting in its expression of those feelings which were universally excited by the sudden removal of a nobleman so much respected and deplored as our late President.

The loss of so many Members by death during the past year has not been compensated to the Society by the number of Members recently elected. The diminution in our strength is a renewed call to exertion on the part of all those who wish well to the Society. The names of candidates for admission will be received with satisfaction by the Council, and not less so those of gentlemen willing to act for the Society in country districts in the capacity of Local Secretaries.

In pecuniary respects the affairs of the Society, as shewn by the report of the Auditors, are entirely satisfactory. With a cash balance more than adequate to discharge all claims and liabilities, and an investment in the Government funds which is of sufficient amount to give permanence to the Society and safety to all the operations of the Council, we stand in a position of peculiar advantage, and are ever ready to undertake any publications which fall within our scope and may be for the benefit of Historical Literature. 
During the past year the following Works have been added to the list of suggested publications:-

I. A Second Volume of Documents connected with James the First's Relations with Germany. To be edited by Samuel Rawson Gardiner, Esq.

II. A Narrative of Proceedings in the Star Chamber and Court of High Commission in the Year 1632. To be edited by John Bruce, Esq. F.S.A.

III. A Spanish Account of the Proposed Marriage between Charles Prince of Wales and the Infanta; by Francesco de Jesus, from an original MS. To be edited, with a Translation, by Samuel Rawson Gardiner, Esq.

IV. A Military Memoir of Colonel Birch, sometime Governor of Hereford during the Civil War. To be edited from the original MS. by the Rev. JoHN WeBB, M.A. F.S.A.

The following are the Books which will be delivered to Members in return for the Subscription due on the 2nd May, 1866 :-

I. Pope Alexander the Seventh and the College of Cardinals. By John Bargrave, D.D. Canon of Canterbury $(1662-1680)$; with a Catalogue of Dr. Bargrave's

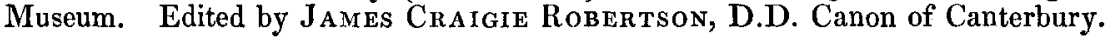

II. Accounts and Papers relating to Mary Queen of Scots. Edited by ALLAN J. Crosby, Esq. and John Bruce, Esq.

Both these have already been issued. They will shortly be followed by-

III. History from Marble. Being Ancient and Modern Funerall Monuments in England and Wales; by Thomas Dingley, Gent. in the reign of Charles II. Reproduced in Fac-Simile of the Original MS. belonging to Sir Thomas Edward Winnington, Bart. M.P. by the process of Photo-Lithography, by Vincent Brooks. With an Introduction by Joms Gough Nichols, Esq. F.S.A. Part I.

There are two points in connection with this interesting volume to which the Council thinks it right to call the attention of the Members. In the first place, the Society is indebted for the use of the original MS. to Sir Thomas E. Winnington, Bart. M.P. it being one of the treasures of his valuable Library at Stanford Court. To the same Library the Society has been indebted on two previous occasions. From it was derived the very important Household Roll of Bishop Swinfield, so admirably edited by the Rev. John Webb; and still more recently the Justification of Queen Elizabeth in relation to her treatment of Mary Queen of Scots, just published by Mr. Bruce. Such reiterated tokens of good-will towards the Society, on the part of Sir Thomas Winnington, will no doubt receive due and hearty recognition from the present Meeting. 
The other point to which the Council desires to refer arises out of the nature of the work entitled "History from Marble."

Thomas Dingley not only inserted in his work copies of Monumental Inscriptions, but also drawings of Monuments, Arms, Brasses, Antiquities, Churches, and Mansions. The expense of reproducing these drawings by any of the ordinary processes used for book-illustration would have been so great, that, although Sir Thomas placed the volume at the disposal of the Society, the Council feared that the Society would not be able to avail itself of his liberality. Neither lithography, wood-engraving, nor any other of the customary processes would have answered the purpose; but, it having been suggested that the book might be reproduced in fac-simile by photolithography, the Council communicated on the subject with Mr. Vincent Brooks, whose skill in such matters is universally acknowledged. Eventually the volume has been placed in his hands for production in fac-simile; and, to make the publication in every way satisfactory, Mr. Nichols, who is already well acquainted with Dingley's labours, has kindly undertaken to prefix such an introduction as may be necessary, and to superintend the production of the volume.

The Camden Society is doing, it will be perceived, for Dingley's Manuscript, what the Government has done for Domesday Book, and is doing for a series of Historical Documents, with this addition, that those publications are mere fac-similes of manuscripts, whilst Dingley is full of pictorial illustration interwoven with the text. The process employed is one which, when public attention has been thoroughly drawn to it, may work important changes in the mode of publishing manuscripts, especially where, as in Dingley's case, there are drawings combined with literary or historical matter. It therefore especially deserves the attention of all antiquarian and publishing Societies. Dingley's work, the Council trusts, will be doubly welcome to the Society, both from its own intrinsic curiosity, and from the novelty of the mode of production.

By order of the Council,

John BRuce, Director.

24 th April, 1867.

William J. Thoms, Secretary. 


\section{REPORT OF THE AUDITORS.}

We, the Auditors appointed to audit the Accounts of the Camden Society, report the Society, that the Treasurer has exhibited to us an Account of the Receipts and xpenditure from the 15th of April 1866, to the 31st of March 1867, and that we .ve examined the said accounts, with the vouchers relating thereto, and find the same be correct and satisfactory.

And we further report that the following is an Abstract of the Receipts and. xpenditure during the period we have mentioned.

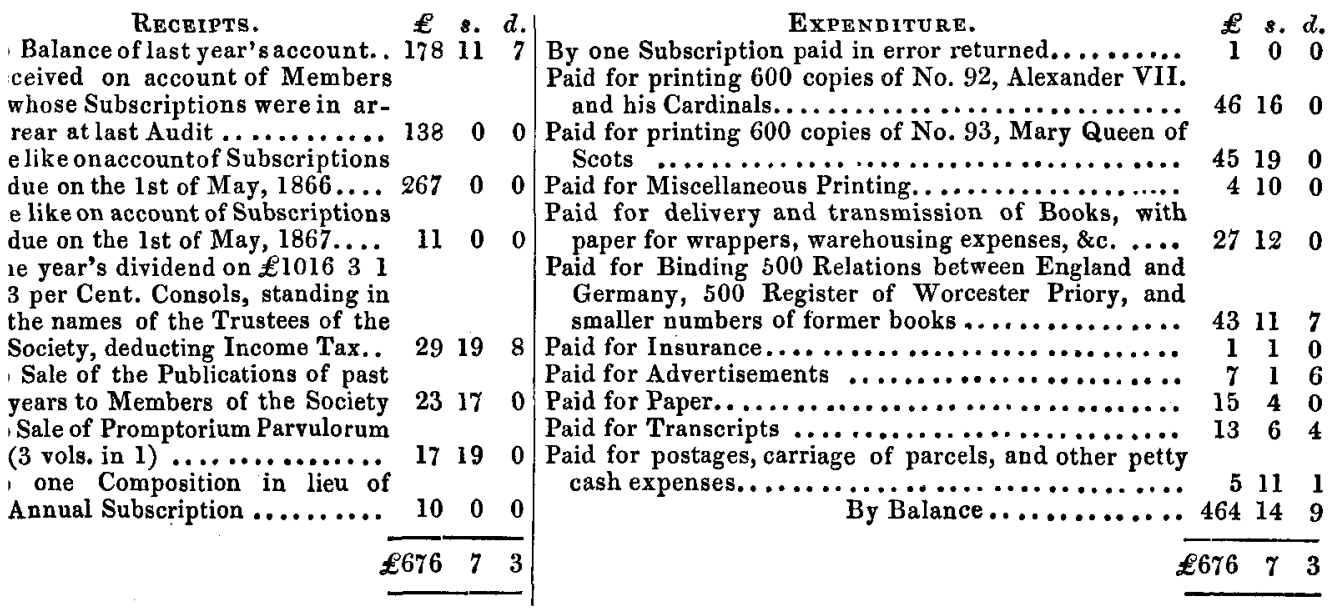

And we, the Auditors, further state, that the Treasurer has reported to us, that rer and above the present balance of $£ 464$ 14s.9d. there are outstanding various subriptions of Foreign Members, and of Members resident at a distance from London, hich the Treasurer sees no reason to doubt will shortly be received.

Hen. Hill.

William Douglas Hamilton.

23rd April, 1867. 


\section{LAWS OF THE CAMDEN SOCIETY.}

I. That the Society shall be entitled "The Camden Society, for the Publication of Early Historical and Literary Remains."

II. That the objects of the Society shall be, First, the publication of inedited Manuscripts ; Second, the reprinting of Works of sufficient rarity and importance to make Reprints desirable; and Third, the publication of Translations of Historical Works not previously rendered into English.

III. That the Society shall consist of One Thousand Two Hundred Members, being Subscribers of One Pound annually; such Subscription to be paid in advance, on or before the first day of May in every year.

IV. That the management of the affairs of the Society shall be vested in a President and a Council consisting of fifteen Members, which President and Council shall be elected annually by the Society at large, at a General Meeting to be held on the 2nd day of May, being the Anniversary of Camden's birth ; or on the Monday following, when the 2nd of May shall happen to fall upon a Sunday.

V. That the President and Council shall, from amongst their own body, elect a Director, who shall act as Chairman of the Council in the absence of the President, and also a Treasurer, and a Secretary.

VI. That the Accompts of the Receipts and Expenditure of the Society shall be audited annually by three Auditors, to be elected at the General Meetings, and that the Report of the Auditors, with an Abstract of the Accompts, shall be published.

VII. That the names of Members proposed to be elected as President, Council, and Auditors, shall be transmitted by the proposers to the Secretary, one fortnight before the General Meeting, and that notice of the persons so proposed shall be forwarded by the Secretary, one week before the General Meeting, to all the Members residing within the limits of the Twopenny Post, and to all other Members who shall, in writing, request to receive the same.

VIII. That no Member shall be entitled to vote at any General Meeting whose Subscription is in arrear.

IX. That in every year one-fifth in number of the Council of the year preceding shall be ineligible for re-election; and that in case any Member of the Council shall not attend more than one-third of the number of Meetings of the Council, such measure shall be considered to be one of the retiring Members.

$X$. That in the absence of the President and Director, the Council at their Meetings shall elect a Chairman, who shall have a casting vote in 
case of equality of numbers, and shall also retain his right to vote upon all questions submitted to the Council.

XI. That the Funds of the Society shall be dishursed in payment of necessary expenses incident to the production of the Works of the Society, and that all other expenses shall be avoided as much as possible.

XII. That, after the Members of the Society shall have reached One Thousand Two Hundred, vacancies in that number shall be filled up by the Council, from time to time as they occur.

XIII. That every Member not in arrear of his Annual Subscription, shall be entitled to One Copy of every Work published by the Society during that year.

XIV. That the Members shall be invited to contribute or recommend Works for publication.

XV. That Editors of Works printed by the Society shall be entitled to Twenty-Five Copies of the Works they edit.

XVI. That the Council shall determine what number of copies of each Work shall be printed, and that the copies over and above those required by the Members shall be sold in such manner, and at such prices, as shall be fixed by the Council, the proceeds being carried to the account of the Society.

XVII. That the Publications of the Society shall all form separate and distinct Works, without any other connexion than that which must necessarily exist between the volumes of such Works as consist of several Volumes.

XVIII. That any Member of the Society may at any time compound for his future Annual Subscriptions, by payment of $£ 10$ over and above his Subscription for the current year.

XIX. That every Member of the Society who shall intimate to the Council his desire to withdraw from the same, or who shall not pay his Subscription for the current year within three Months after his Election, or after such Subscription shall have become due, shall thereupon cease to be a Member of the Society.

XX. That the Council may appoint Local Secretaries in such places, and with such authorities as to them shall seem expedient; every Local Secretary being a Member of the Society.

XXI. That no alteration shall be made in these Laws, except at a General Meeting, nor then, unless One Month's notice of any alteration intended to be proposed at such Meeting shall have been given in writing to the Secretary. 